\title{
Return migrant status and employment in Finland
}

\author{
Jan Saarela and Fjalar Finnäs \\ Åbo Akademi University, Vaasa, Finland
}

\begin{abstract}
Purpose - The purpose of this paper is to examine the relative employment levels of return migrants in Finland with regard to their re-adaptation into the labour market.

Design/methodology/approach - Longitudinal census data distinguished Finns who had lived abroad and returned to Finland. These return migrants are compared with non-migrants with regard to employment levels, using logistic regression models that account for sex, age, education, mother tongue and place of residence.

Findings - Both male and female return migrants have odds of employment that are only about half those of their non-migrant counterparts. The employment differential is stable over time and, consequently, not particularly sensitive to changes in the macroeconomic environment. Relative employment rates of migrants with short periods abroad and long periods in the home country are somewhat higher than those of other migrants, but still lower than those of non-migrants. Difficulties in readapting into Finnish society are consequently associated with personal characteristics that cannot be observed explicitly but are apparently associated with job-finding probability.

Practical implications - Considering that Finland at present has no explicit measures directed towards return migrants, it is suggested that this group should be given more policy attention.

Originality/value - The paper provides quantitative evidence that Finnish migrants have substantial difficulties in finding employment in the home country labour market subsequent to return migration, and that these problems cannot be attributed to structural factors.
\end{abstract}

Keywords Migrant workers, Employment, Finland

Paper type Research paper

\section{Introduction}

There has been free mobility of labour in the Nordic countries ever since 1954 (see Saarela and Rooth, 2006). The entry of large birth cohorts within the Finnish labour market and labour shortages in many industries in Sweden has led to substantial migration flows from Finland to Sweden. Until the early 1970s, the net migration loss amounted to 180,000 persons. Thereafter, increasing numbers of Finnish migrants began to return to their home country, and the size of the return migration flows were then approximately equal to the migration flows (Figure 1).

Half a million Finns migrated during the second part of the 20th century, but more than half of them eventually returned to Finland. Consequently, at least every twentieth person in the country's current population has lived abroad, and over three quarters of them have been staying in Sweden. Practically all the immigrant flow until the 1990s consisted of return migrants, because Finland did not experience any immigration of foreign-born persons (Institute of Migration, 2006; Statistics Finland, 2006a).

From an international perspective, similarly large flows of return migrants are not exceptional (see Dustmann, 1996; Constant and Massey, 2003). What is unusual with the Finnish case is that we can observe them in the source country subsequent to

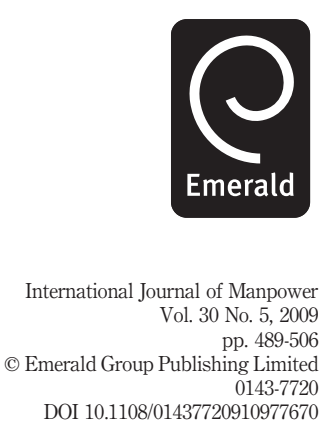


IJM

30,5

490

Figure 1.

Migration from and to Finland 1945-2001

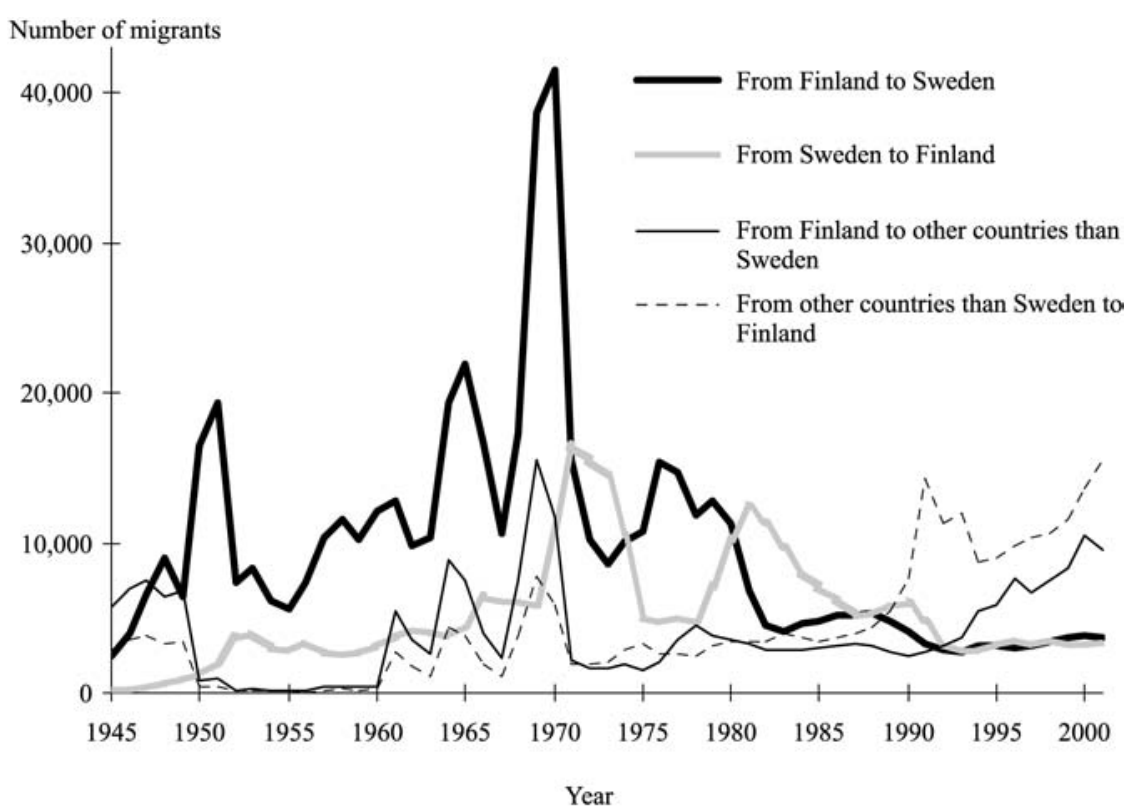

Source: Institute of Migration (2006)

return migration whereas more commonly, return migrants tend to be viewed as foreign-born people who migrate from the host country (see Dumont, 2005; IOM, 2006; OECD, 2007).

Migration policies in Finland were, for a long time, affected by the substantial number of people who migrated. Many political intentions were to check migration flows and promote return migration flows. Indeed return migrants tended to be viewed from a broad human resource perspective, as creative and social beings contributing to Finnish society (beyond just providing labour). As a result, many commission reports discussed how to ease the process of readapting for return migrants, in terms of issues such as work environment, housing markets, social benefits, education, culture, and employment opportunities (see, for example, CR, 1976, 1980, 1986).

However, no large-scale quantitative study was undertaken as the basis for these assessments, or as a follow-up of the Finnish return migrants' situation. This corresponds with the situation elsewhere in the world. In spite of large rates of return migration, and the consequences for population development, direct knowledge about the adaptation of return migrants' in the home country is very limited. Primarily, this is because most countries have no population registers that allow researchers to distinguish people who have lived abroad (in any other way than by undertaking surveys).

Finland is an exception in that respect. The country has a population register that covers the total population, in which each person can be identified in concurrent censuses and return migrants can be distinguished. All data are based on existing population files, so there are no missing observations and no individual recall bias. 
These population files can also be linked to other existing registers, such as those containing labour force statistics.

In this paper, we make use of the possibilities offered by Finnish data to study the employment levels of return migrants, and to compare them with non-migrants when accounting for structural confounders. A person who is employed subsequent to having return migrated is considered to be successfully reintegrated in the home country, similar to the common way of treating employed immigrants in any given host country as successfully integrated (Arowolo, 2000; OECD, 2001). Of central interest is the role played by migration duration and duration subsequent to return migration.

Previous analyses that use census data for studying return migrants' relative employment rates are very scarce. A study by Muschkin (1993), which was based on data from the 1970 and 1980 population censuses of Puerto Rico, found that Puerto Ricans who had returned to their home country from the United States had notably lower adjusted employment rates than non-migrants had. The results were explained by the changing context in which the return migrants were seeking employment, which was argued to override any potential gain that may accrue through the migration process. Lost contact with the home country labour market consequently seemed to have made the return migrants particularly vulnerable to discontinuities in employment.

Circumstances that have promoted migration between Finland and Sweden correspond highly with those that have influenced migration between Puerto Rico and the United States (see, e.g. Ramos, 1992; Rooth and Saarela, 2007). Besides free mobility of labour, there are many institutional similarities and a common history. However, unlike the data used for this study, the Puerto Rican censuses were not linked; therefore, Muschkin could not observe the same individuals over time.

For some individuals, foreign work experience and other practices gained abroad obviously assist in developing investment in their career potential. However, based on previous studies of migrants from Finland and Finnish immigrants in Sweden, one cannot expect that the Finnish return migrants should be competitive in the home country labour market subsequent to return. Non-employed Finns have been found to have both higher migration rates from Finland, and higher return migration rates from Sweden, as compared with employed Finns (Finnäs, 2003; Saarela and Finnäs, 2006). This may partly be due to inadequate skills, as Finnish migrants tend to have relatively low educational levels (Finnäs, 2003; Rooth and Saarela, 2007). Other findings also say, however, that individual employment propensities correlate heavily across countries and time (Saarela and Finnäs, 2008). Unobservable factors might therefore also be important.

Where migrants experience difficulties in reintegration in terms of low employment rates because of lost contact, this is likely to be manifest in two specific ways (see Chiswick, 1978; Lichter, 1983; Maxwell, 1988; Borjas et al., 1992; Muschkin, 1993). First, network ties to the home country labour market can be expected to weaken with time spent abroad, and improve with time spent in the home country. Relative employment opportunities of return migrants would then correlate negatively with migration duration, and positively with duration subsequent to return migration, factors which are examined in this paper.
Return migrant status

491 
IJM

30,5

492

\section{Data and settings for analysis}

The census data were drawn from the Finnish longitudinal census data file compiled by Statistics Finland. The files consist of linked individual information from the censuses at the end of the years 1970, 1975, 1980, 1985, 1990 and 1995 (Statistics Finland, 2006b). Data take the form of a multidimensional matrix that includes all individuals and information about their year of birth, sex, educational level, mother tongue, region of residence and employment status.

The Lexis diagram in Figure 2 illustrates the observation plan. Under analysis are people born in the years 1951 to 1970, subject to that they were living in Finland at ages 15-19 years. These persons can be expected to make an autonomous migration decision. Older cohorts are also included (people aged 20-34 years in 1970; born 1936-1950), subject to that they were living in Finland at the time of the 1970 census. Some of these could have been abroad before that census, but they were born in Finland. We have no explicit information about the country from which the migrants had returned, but since we are primarily concerned with the period prior to the mid-1990s, return migrants as discussed here should be understood as Finns who have return migrated from Sweden.

Given these conditions, we define return migrants as people who were living abroad at one or more of the subsequent censuses, and had returned to Finland by the 1995 census at the latest. Consider for instance people born 1951-1955, i.e. those aged 15-19 years in 1970 and living in Finland at that time. In this birth cohort, a person defined as a return migrant had emigrated abroad by the 1975, 1980, 1985 or 1990 census, and had stayed abroad for any number of subsequent censuses until being observed again in Finland (in the 1995 census at the latest).

For all birth cohorts under study, the number of return migrants is given in Table I by the particular census (or censuses) the return migrants were abroad and the census (or censuses) they participated in thereafter are observed in the home country. The illustration is for men and women separately. For sake of simplicity, we consistently focus on the first return migration. Repeat migrants and people who died were treated as right-censored observations at the time they cannot be observed in a census. This is the reason why the number of return migrants, for any given census abroad, diminishes over time. The large number of return migrants who were abroad at the time of the 1980 census (approximately three times as many as at the time of any of the other three censuses) is due to the large migration flows from Finland to Sweden in the late 1970s and from Sweden to Finland in the early 1980s (see Figure 1).

The final column for each sex refers to the number of non-migrants in the same birth cohorts. Non-migrants are defined as persons who were living in Finland at the time of all the censuses, which implies that the number of people in this group is constant over time (over censuses after the migrants had returned). In total, we observe 40,304 return migrants and 2,394,181 non-migrants.

Return migration rates to Finland tend to be very high during the first few years after migration, so that almost every second migrant returns within three years (Finnäs, 2003). In common with these earlier findings, approximations undertaken here indicate that persons classified as return migrants in the census data amount to one quarter of all return migrants. Analyses of the census data are therefore, by definition, concerned with return migrants with relatively long stays abroad. 


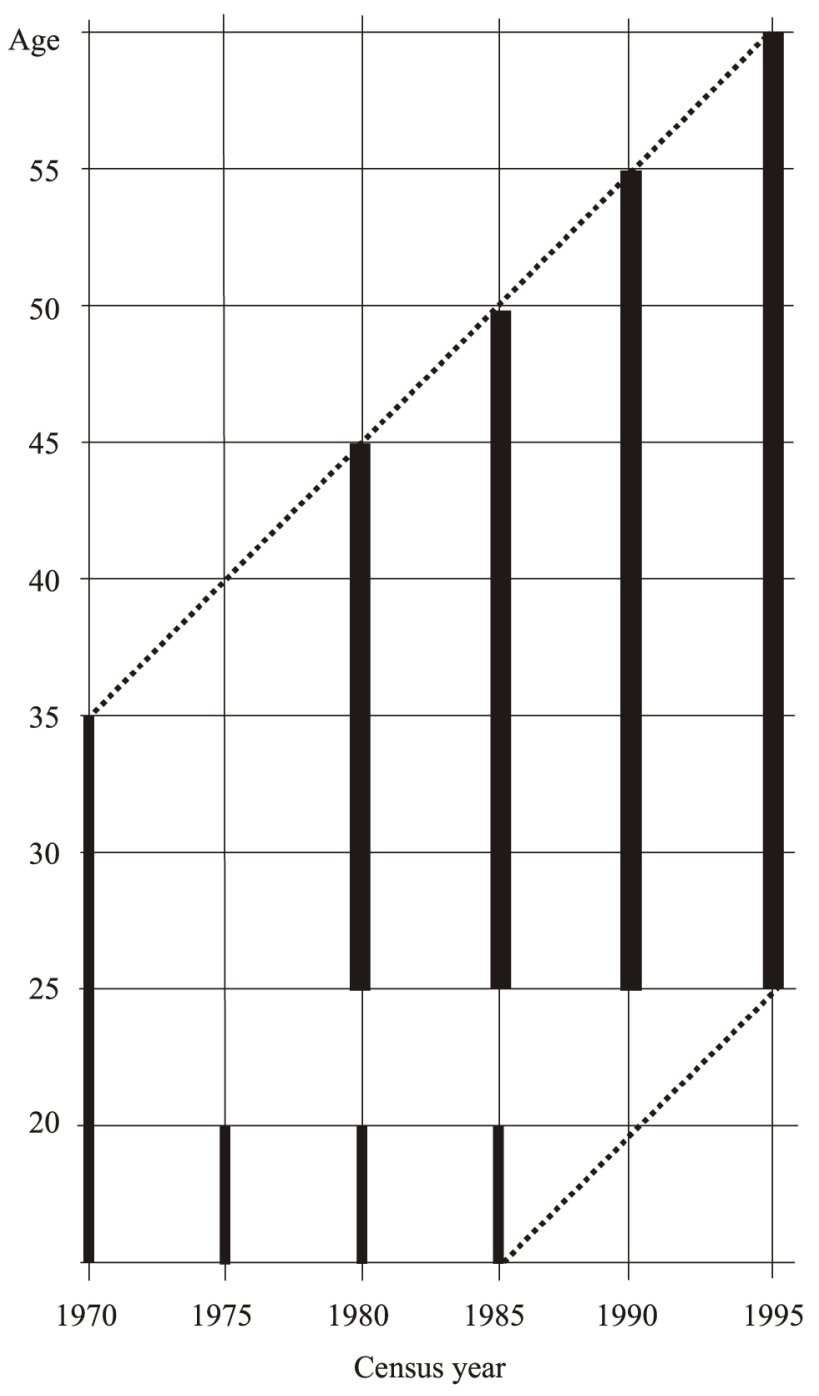

Notes: The thin bars represent the target population in the sense that persons under study were living in Finland at these ages and points of time. The thick bars represent the period and age in which each person may be analysed with regard to employment
Return migrant

status

493
Figure 2. Lexis diagram of the observation plan for the census data

Within the group of people categorised as non-migrants, there are consequently persons who had lived abroad at some time. These people have both migrated and return migrated between two consecutive censuses, and had thus stayed abroad for a maximum of five years. They amount to approximately five per cent of all persons categorised as non-migrants. If return migrants as a group have lower employment 
IJM

30,5

494

Table I.

Number of return migrants by the census(es) when they were abroad and the census(es) when they were observed in Finland subsequent to return migration, and the number of non-migrants in the same birth cohorts

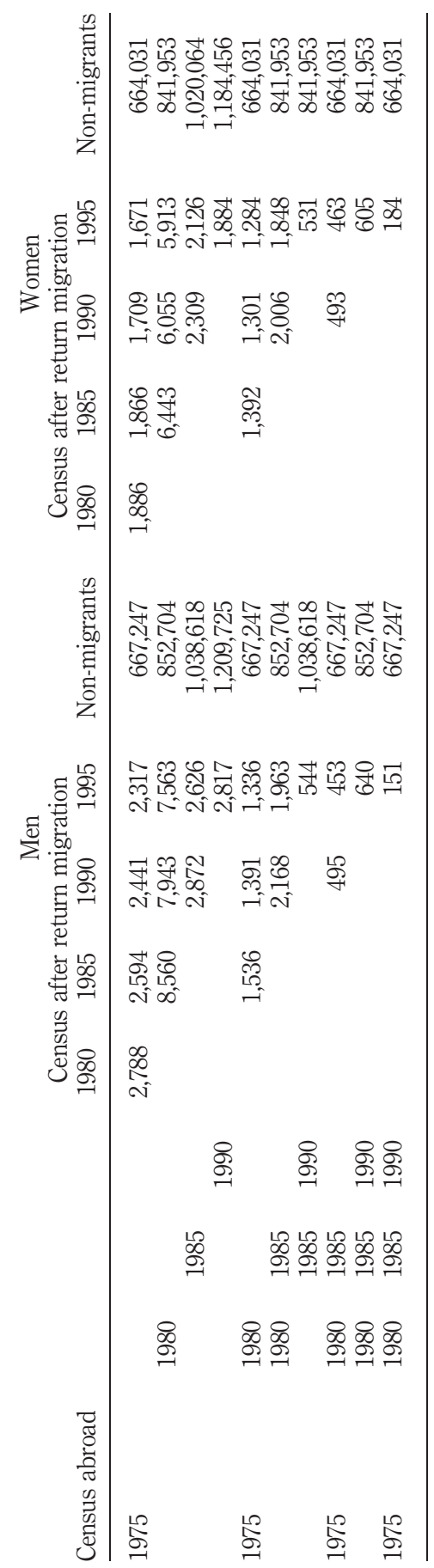


rates than non-migrants, observed differences in the data will therefore slightly underestimate the true difference.

Besides the census data, which covers the total population in certain birth cohorts at the end of every fifth year from 1970 until 1995, we also use complementary data that contains annual information for the period 1987-1999. Both data sets are based on the population registers, but the latter is in the form of a random sample due to confidentiality reasons.

The annual complementary data are an extract from Statistics Finland's longitudinal population register file Työssäkäyntitilasto (Statistics Finland, 2006c). It is very similar in nature, and partly based on the census file described above. In contrast with the census data, it gives all information on an annual basis for the years 1987 to 1999, and therefore facilitates more detailed analyses, but for fewer individuals and somewhat shorter periods. These data are in the form of a random sample, comprising 5 per cent of all Finnish speakers and 20 per cent of all Swedish speakers. It focuses on the Southern and Western parts of Finland, which cover a fourth of the total population of the country. For each individual and year, there is information about whether the person was living in the country, was living abroad, or had died. In addition to year of birth, sex and mother tongue, variables that measure each person's level and field of education, municipality of residence, and employment status at the end of each year are also included. Since the data are annual we observe all return migrants who had stayed abroad over the course of the year, and can thus measure time abroad and time in the home country with reasonably good accuracy.

Data from the censuses will give a comprehensive picture for long periods, whereas the annual data facilitate analyses for shorter periods, with more detailed focus on migration duration and duration subsequent to return migration.

The observation plan for the annual data corresponds highly with that used for analysing the census data. Under study are people born 1973-1982, subject to that they were living in Finland at 15 years of age. Also included are persons born 1940-1972 (aged 16-48 years in 1987), if they were living in Finland at end-1987. Return migrants are defined as persons who were living abroad at one or more of the years subsequent to having been observed in Finland, and who had returned to Finland by end-1999 at the latest. They amount to 1,238 individuals. Non-migrants are defined as persons in the same birth cohorts, who had been living in Finland at the end of all of the years 1987 to 1999. They amount to 88,564 individuals.

\section{Results}

\subsection{Relative employment of return migrants}

Analyses of the census data clearly revealed that, return migrants have notably lower employment levels than non-migrants. This is illustrated in Table II, which gives aggregate employment rates of return migrants by the specific census (or censuses) the persons were abroad and the subsequent census (or censuses) after having return migrated. The difference was surprisingly consistent across censuses in spite of employment rates that varied considerably due to changes in the macroeconomic environment.

Those who have return migrated during economic recessions are found to have poorer relative performance than those who return migrated during economic upswings,
Return migrant

status

495 
IJM

30,5

\section{6}

\section{Table II.}

Employment rate of return migrants by the census(es) when they were abroad and the census(es) when they were observed in Finland subsequent to return migration, and of non-migrants in the same birth cohorts (\%)

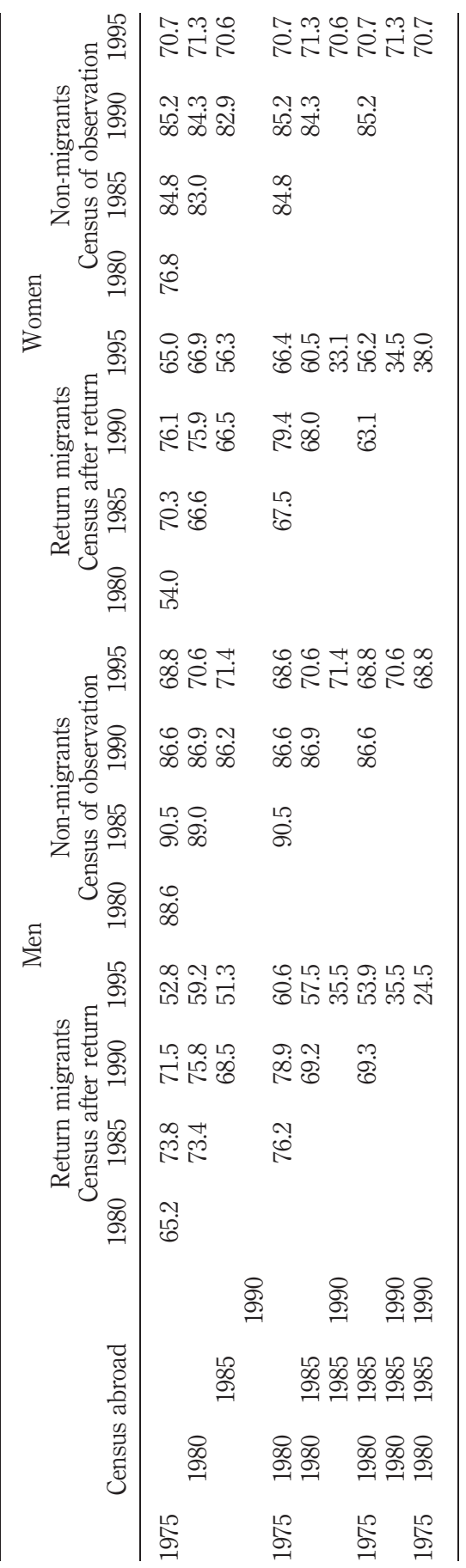


probably because job competition is then stronger and contacts with the home country labour market more important. Between 1976 and 1978, unemployment rates in Finland tripled from two and a half to over seven per cent, but by the end of 1980, they had fallen back to just below five per cent. Return migrants were obviously more vulnerable than non-migrants were to these circumstances. Men who return migrated during the second part of the 1970s had an employment rate in 1980 that was only 65 per cent, as compared with an employment rate of almost 90 per cent for male non-migrants in 1980. A similar pattern can be observed for women, and for people who return migrated in the early 1990s when unemployment rates in Finland increased dramatically from under seven to over 15 per cent. The best relative performance is found for people who return migrated when unemployment rates were low in the 1980s.

To improve readability, the employment rates were transformed into relative differences in employment levels between return migrants and non-migrants, in terms of odds ratios (Table III). For instance, in 1980 male return migrants had an employment rate of 65.2 per cent, whereas the corresponding number for non-migrants was 88.6 per cent. This corresponds to an odds ratio of 0.241 [(0.652/(1-0.652)]/ [0.886/(1-0.886)], which says that return migrants had 76 per cent lower odds of being employed than non-migrants.

For this specific migrant group, the odds ratio gradually increased with time spent in Finland, to 0.298 in 1985, 0.382 in 1990 and 0.494 in 1995. A similar pattern applies to people who had been living abroad at other censuses, and to women. Hence, as suggested by the argumentation of lost contact, the relative employment levels of return migrants tend to improve with time spent in the home country, but they remain lower than those of non-migrants.

There is also some evidence for an inverse relationship between migration duration and reintegration opportunities. As compared with male non-migrants in 1995, the odds ratio for the employment of men who return migrated during the early 1990 s was 0.361 for those with only one census abroad, 0.220 for those with two censuses abroad, 0.229 for those with three censuses abroad, and 0.147 for those with all four censuses abroad. A similar negative association cannot be observed in the other censuses, however. For women there is still quite a clear difference, specifically when return migrants with only one census abroad are compared with those with more than one census abroad.

\subsection{The role of structural factors}

To account for differences in characteristics between return migrants and non-migrants, we estimated logistic regression models that included age, educational level, mother tongue and region of residence. Results of these estimations are in Table III included as odds ratios within parentheses, together with the unadjusted odds ratios outside parentheses. The above conclusion largely remains. The employment differential cannot be attributed to structural factors, because in very many instances it becomes even more pronounced when these variables are accounted for. In spite of Swedish-speaking Finns having higher migration rates and lower return migration rates than Finnish-speaking Finns (Finnäs, 1986; 2003), patterns for the estimated parameters turned out to be very similar across language groups (not shown). Therefore, mother tongue was estimated to account for a difference in employment
Return migrant status 
IJM

30,5

\section{8}

Table III.

Odds for employment of return migrants in relation to odds for employment of non-migrants

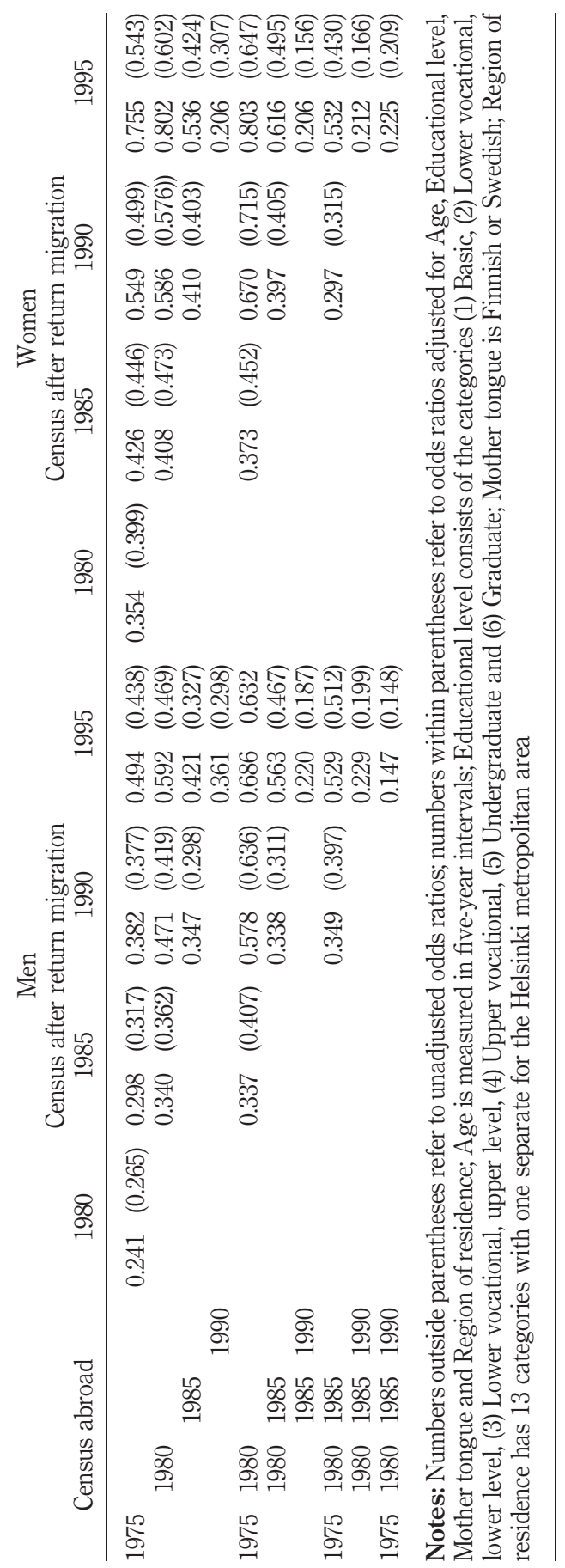


rates that generally goes in favour of the Swedish-speaking Finns (Saarela and Finnäs, 2003).

Higher-educated return migrants' employment rates were substantially higher than lower-educated return migrants', but still lower than the employment rates of higher-educated non-migrants. Male non-migrants with basic education had an employment rate of 59.7 per cent in 1995, those with vocational education 73.5 per cent, and those with undergraduate or higher education 87.2 per cent. Corresponding numbers for male return migrants who had only been abroad for the 1990 census were 27.4, 48.9 and 81.8 per cent, respectively (not shown in table). In order to establish whether there was any variation in the rate of improvement over time across educational levels, we estimated separate regressions for people with:

- basic education;

- vocational education; and

- undergraduate or higher education.

Heterogeneity in the return-migrant group was reduced by focusing on people who had been only one census abroad. The results, which are summarised in Table IV, reveal that not even highly educated return migrants manage over time to come close to the employment levels of non-migrants. Behavioural variation across differently educated return migrants does not consequently confound the earlier results.

\subsection{Migration duration and subsequent return migration}

The census data revealed that the return migrants' relative employment rates improved with duration subsequent to return migration, whereas the interrelation with

\begin{tabular}{|c|c|c|c|c|c|c|c|c|c|}
\hline \multirow{3}{*}{$\begin{array}{l}\text { Census abroad } \\
1975\end{array}$} & \multirow[b]{2}{*}{ Educational level } & \multicolumn{4}{|c|}{$\begin{array}{c}\text { Men } \\
\text { Census after return migration }\end{array}$} & \multicolumn{4}{|c|}{$\begin{array}{c}\text { Women } \\
\text { Census after return migration }\end{array}$} \\
\hline & & 1980 & 1985 & 1990 & 1995 & 1980 & 1985 & 1990 & 1995 \\
\hline & Low & 0.227 & 0.328 & 0.369 & 0.423 & 0.374 & 0.409 & 0.443 & 0.520 \\
\hline & Semi & 0.320 & 0.272 & 0.347 & 0.413 & 0.422 & 0.509 & 0.525 & 0.575 \\
\hline & High & 0.446 & 0.552 & 0.641 & 0.641 & 0.407 & 0.352 & 0.753 & 0.486 \\
\hline \multirow[t]{3}{*}{1980} & Low & & 0.314 & 0.410 & 0.451 & & 0.434 & 0.508 & 0.538 \\
\hline & Semi & & 0.376 & 0.410 & 0.473 & & 0.490 & 0.639 & 0.660 \\
\hline & High & & 0.530 & 0.473 & 0.477 & & 0.522 & 0.523 & 0.561 \\
\hline \multirow[t]{3}{*}{1985} & Low & & & 0.261 & 0.258 & & & 0.343 & 0.327 \\
\hline & Semi & & & 0.310 & 0.345 & & & 0.444 & 0.476 \\
\hline & High & & & 0.418 & 0.510 & & & 0.503 & 0.505 \\
\hline \multirow[t]{3}{*}{1990} & Low & & & & 0.232 & & & & 0.253 \\
\hline & Semi & & & & 0.304 & & & & 0.318 \\
\hline & High & & & & 0.568 & & & & 0.381 \\
\hline
\end{tabular}

Notes: The odds ratios are adjusted for Age, Mother tongue and Region of residence; data on return migrants are restricted to those who had been one census abroad; the results are based on regressions estimated separately across sexes, censuses, and educational levels; Low refers to people with basic education only, Semi to those with vocational education, and High to those with undergraduate or higher education

\section{Return migrant status}

499

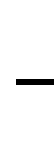


IJM

30,5

500

the duration of migration appears to be more ambiguous. To use more precise duration measures, we analysed the annual data. Return migrants were categorised into subgroups according to the number of years they had spent abroad and the number of years they had spent in the home country subsequent to return migration, respectively. Results of logistic regression models that estimate adjusted odds ratios for employment of return migrants in relation to non-migrants are summarised in Figures 3-6. The former depicts the situation by duration subsequent to return migration and the latter by migration duration. The nature of the data implies that the number of observations is relatively few for longer durations. In the figures, we therefore illustrate the situation for up to seven years in the home country and six years abroad. Confidence intervals are outlined in order to give some insight concerning the statistical power of the estimated parameters.

Based on the results it is evident that the relative employment opportunities of return migrants tend to increase with duration subsequent to return migration and decrease with migration duration. The variation between sexes is small, specifically when considering that women are more likely than men to be "tied movers" and not equally attached to the labour market (Mincer, 1978; Boyle et al., 2001).

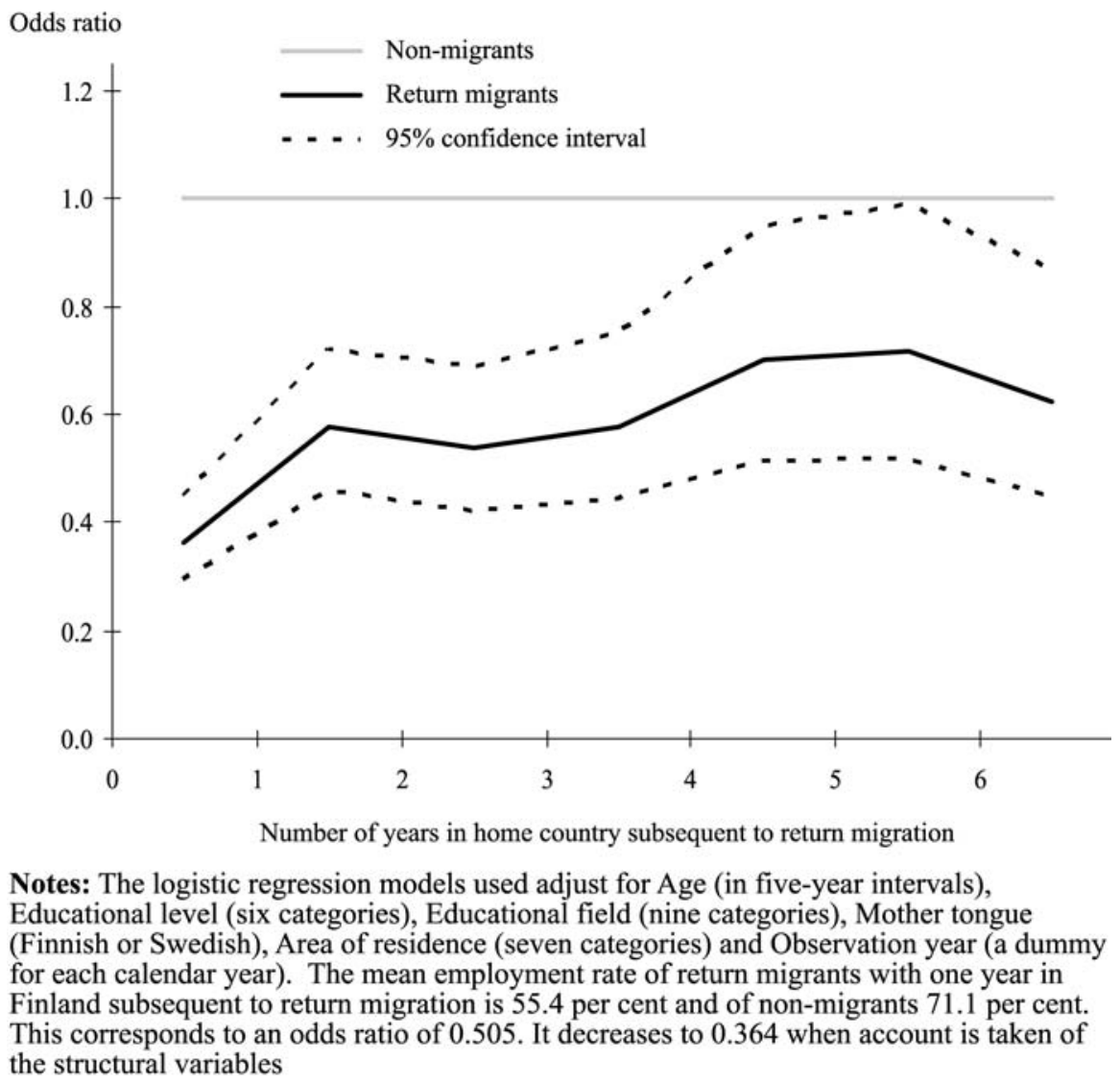

Figure 3.

Odds for employment of return migrants in relation to odds for employment of non-migrants, by duration subsequent to return migration, men 
Odds ratio

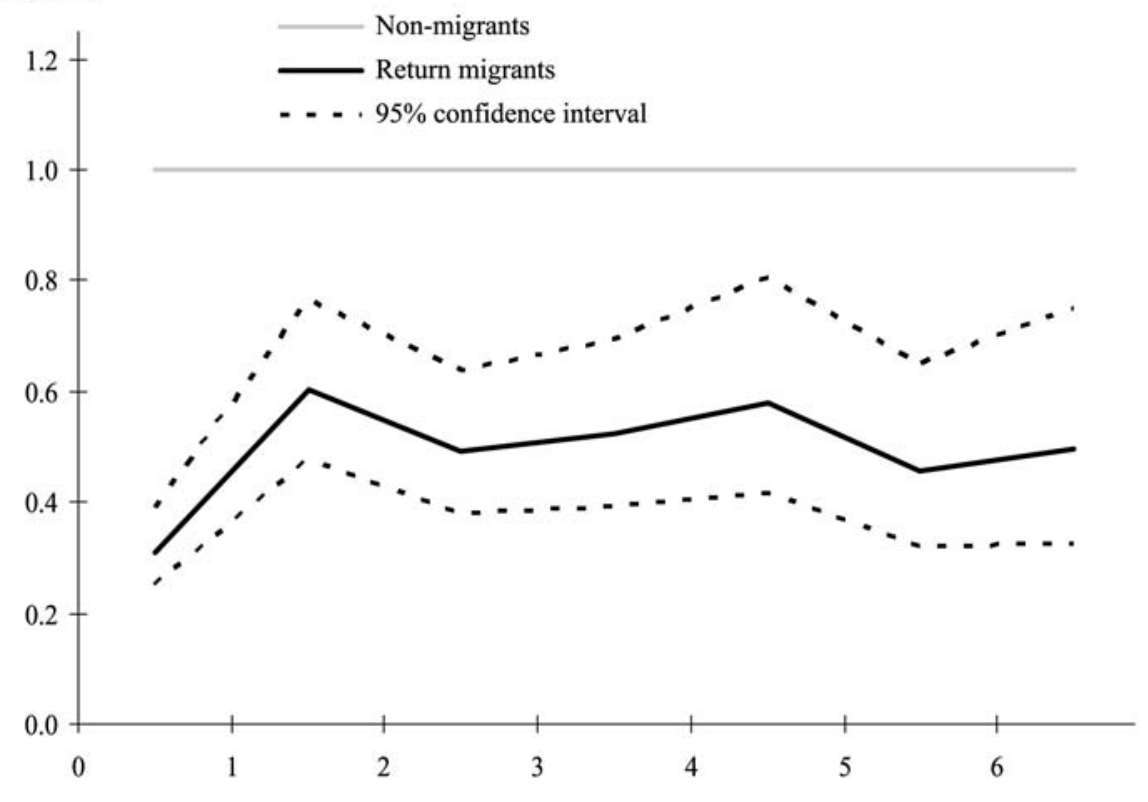

Number of years in home country subsequent to return migration

Notes: The logistic regression models used adjust for Age (in five-year intervals), Educational level (six categories), Educational field (nine categories), Mother tongue (Finnish or Swedish), Area of residence (seven categories) and Observation year (a dummy for each calendar year). The mean employment rate of return migrants with one year in Finland subsequent to return migration is 46.3 per cent and of non-migrants 70.0 per cent. This corresponds to an odds ratio of 0.370 . It decreases to 0.311 when account is taken of the structural variables

\section{Return migrant status}

501

Figure 4.

Odds for employment of return migrants in relation to odds for employment of non-migrants, by duration subsequent to return migration, women

During the first year subsequent to return migration, migrants have particularly low odds of employment. Thereafter slight progress is observed towards a catching-up effect for men, as the gap in relation to non-migrants decreases with time spent in the home country. However, even after five or six years, return migrants have not reached parity with non-migrants, as the odds of employment are still about 30 per cent lower. For female return migrants no progress in relative opportunities is apparent at all after the second year in the home country, which places them at approximately 50 per cent lower odds of employment than non-migrants.

Return-migrating men who had been only one year abroad have odds ratios of employment that are 35 per cent lower than those of non-migrants, whereas those of return migrants who had been six years abroad, say, are as much as 55 per cent lower. The corresponding numbers among women are 45 per cent and 60 per cent, respectively. Hence, in spite of the non-linear pattern, it suggests that the employment disadvantage of return migrants, in terms of odds ratios related to non-migrants, decreases with almost five per cent per additional year the return migrant had been abroad. 
IJM

30,5

502

Figure 5.

Odds for employment of return migrants in relation to odds for employment of non-migrants, by migration duration, men

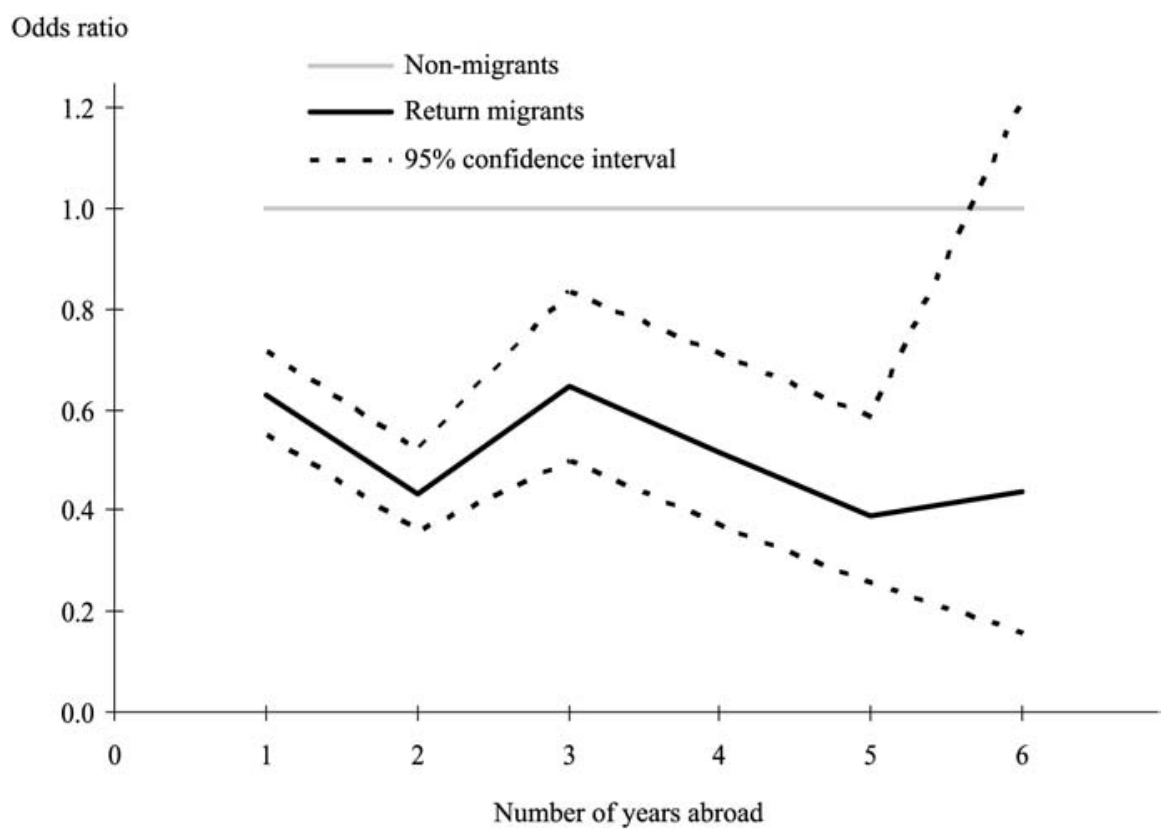

Notes: The logistic regression models used adjust for Age (in five-year intervals), Educational level (six categories), Educational field (nine categories), Mother tongue (Finnish or Swedish), Area of residence (seven categories) and Observation year (a dummy for each calendar year). The mean employment rate of return migrants with one year abroad is 65.7 per cent and of non-migrants 71.1 per cent. This corresponds to an odds ratio of 0.777 . It decreases to 0.628 when account is taken of the structural variables

\section{Conclusions}

A primary goal of the recent political agenda in Finland is to promote the immigration of foreign-born labour. Government representatives strongly argue that immigrants have the potential of filling the demand for labour needed due to changes in the age structure of the population. As compared with the restrictive migration policies practiced in Finland until now, this is a dramatically revised strategy. Practically all discussion in this context has concerned people born in countries other than Finland, who lack experience of the Finnish labour market.

At present Finland has no policy measures that are explicitly targeted towards return migrants. The government's most recent migration policy programme does not even recognise them as a group of particular interest (Ministry of Labour, 2006). This is in contrast with the situation in the 1970s and 1980s, when there was much policy discussion about promoting return migration and facilitating the re-adaptation of return migrants.

Thus, present policies appear to overlook the human resource implications of Finns who have lived abroad. A likely reason could be that they are implicitly assumed to be familiar with the Finnish labour market and thus fully reintegrated. However, 
Odds ratio

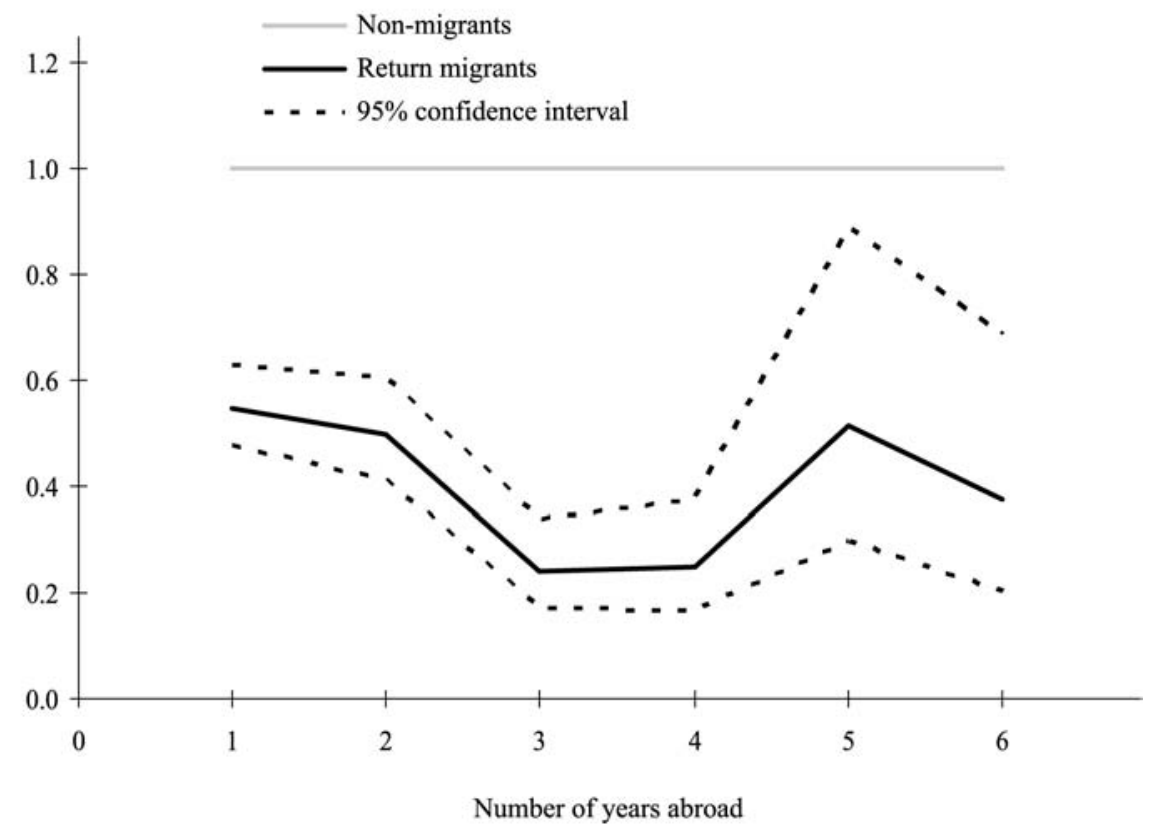

Note: The logistic regression models used adjust for Age (in five-year intervals), Educational level (six categories), Educational field (nine categories), Mother tongue (Finnish or Swedish), Area of residence (seven categories) and Observation year (a dummy for each calendar year). The mean employment rate of return migrants with one year abroad is 58.6 per cent and of non-migrants 70.0 per cent. This corresponds to an odds ratio of 0.608 . It decreases to 0.549 when account is taken of the structural variables

\section{Return migrant status}

503

Figure 6.

Odds for employment of return migrants in relation to odds for employment of non-migrants, by migration duration, women

measures that appear effective in integrating foreign-born persons might not be equally well suited for reintegrating Finnish-born return migrants.

As this paper has shown, there is an obvious rationale for decision makers to be more concerned with the issue of how migrating Finns cope in the labour market having returned home. We find that Finnish return migrants have odds of employment that are only about half those of non-migrants, which might reflect difficulties with their reintegration into Finnish society. The results are roughly similar for men and women, and cannot be attributed to structural factors such as age, education, mother tongue, place of residence, or macroeconomic environment. Even for highly educated people, return migrants had poorer performance in the job market than people who had not lived abroad. Hence, in spite of increased political interest in return migrants in past decades, they have still been in unfavourable labour market positions.

To some extent, return migrants' relative employment rates correlate negatively with migration duration and positively with duration subsequent to return migration. This implies that lost contact with the home country may underlie difficulties in reintegration, and override gains that accrue through the migration process, such as 
IJM

30,5

504 human capital gained from foreign work experience and other work practices gained abroad.

However, migrants who had been abroad for only a short period were also found to have substantially lower employment rates than people who had not lived abroad at all. Return migrants' difficulties in readapting into Finnish society are consequently associated with some personal characteristics that we cannot observe explicitly, but which evidently are highly associated with the job finding probability (see Borjas and Bratsberg, 1996; Rooth and Saarela, 2007).

Identifying what these factors might be and increasing return migrants levels of employment should be considered a unified goal for researchers and policy makers in Finland. There are obvious reasons for attempting to implement policies that facilitate the labour market situation of people who have lived abroad. One possibility is to attempt to identify problem groups at an early stage, before migration or subsequent to return migration. Since all moves are recorded in the population register, this is potentially an accomplishable task. Employment offices might then help regarding advice about how experience gained abroad can prove useful for potential employers. Such strategies would help in developing human resources from the point of view of firms, individuals, and Finnish society.

\section{References}

Arowolo, O.O. (2000), "Return migration and the problem of reintegration", International Migration, Vol. 38, pp. 59-82.

Borjas, G.J. and Bratsberg, B. (1996), "Who leaves? The outmigration of the foreign-born”, Review of Economics and Statistics, Vol. 78, pp. 165-76.

Borjas, G.J., Bronars, S.G. and Trejo, S.J. (1992), "Self-selection and internal migration in the United States", Journal of Urban Economics, Vol. 32, pp. 159-85.

Boyle, P., Cooke, T.J., Halfacree, K. and Smith, D. (2001), "A cross-national comparison of the impact of family migration on women's employment status", Demography, Vol. 38, pp. 201-13.

Chiswick, B. (1978), “The effect of Americanization on the earnings of foreign-born men”, Journal of Political Economy, Vol. 86 No. 5, pp. 897-921.

Constant, A. and Massey, D. (2003), "Self-selection, earnings, and out-migration: a longitudinal study of immigrants to Germany", Journal of Population Economics, Vol. 16, pp. 631-53.

CR (1976), "Sïrtolaisasiain neuvottelukunnan mietintö IV", Commission Report No. 81, Government of Finland, Helsinki.

CR (1980), "Svenska emigrationskommittens betänkande", Commission Report No. 24, Government of Finland, Helsinki.

CR (1986), "Siirtolaisasiain neuvottelukunnan mietintö X”, Commission Report No. 43, Ministry of Labour, Helsinki.

Dumont, J.-C. (2005), "Return migration: policies and practices in Europe", Bulletin of the World Health Organization, Vol. 83 No. 2.

Dustmann, C. (1996), "Return migration: the European experience", Economic Policy, Vol. 22, pp. 213-50.

Finnäs, F. (1986), "Den finlandssvenska befolkningsutvecklingen 1950-1980. En analys av en språkgrupps demografiska utveckling och effekten av blandäktenskap", doctoral dissertation, Åbo Akademi University, Vaasa. 
Finnäs, F. (2003), "Migration and return-migration among Swedish-speaking Finns", in Höglund, R., Jäntti, M. and Rosenqvist, G. (Eds), Statistics, Econometrics and Society: Essays in Honour of Leif Nordberg, Research Reports, No. 238, Statistics Finland, Helsinki.

Institute of Migration (2006), Tilastot, available at: www.migrationinstitute.fi/db/stat/fin/ (accessed December 1, 2006).

IOM (2006), Return Migration: Policies and Practices in Europe, International Organization for Migration, Geneva.

Lichter, D.T. (1983), "Socioeconomic returns to migration among married women”, Social Forces, Vol. 62, pp. 487-503.

Maxwell, N.L. (1988), "Economic returns to migration: marital status and gender differences", Social Science Quarterly, Vol. 69, pp. 108-21.

Mincer, J. (1978), "Family migration decisions”, Journal of Political Economy, Vol. 86, pp. 749-73.

Ministry of Labour (2006), Government Migration Policy Programme, Government Resolution 19.10.2006, Publication, No. 371, Ministry of Labour, Helsinki, available at: www.mol.fi/ mol/fi/99_pdf/fi/06_tyoministerio/06_julkaisut/07_julkaisu/thj371.pdf (accessed December 1, 2006).

Muschkin, C.G. (1993), "Consequences of return migrant status for employment in Puerto Rico", International Migration Review, Vol. 27, pp. 79-102.

OECD (2001), "The employment of foreigners: outlook and issues in OECD countries", OECD Employment Outlook 2001, Vol. 2001, Organization for Economic Co-operation and Development, Paris, pp. 167-206.

OECD (2007), International Migration Outlook: SOPEMI 2007 Edition, Organization for Economic Co-operation and Development, Paris.

Ramos, F. (1992), "Out-migration and return migration of Puerto Ricans", in Borjas, G. and Freeman, R. (Eds), Immigration and the Work Force: Economic Consequences for the United States and Source Areas, University of Chicago Press, Chicago, IL, pp. 49-66.

Rooth, D.-O. and Saarela, J. (2007), "Selection in migration and return migration: evidence from micro data”, Economics Letters, Vol. 94, pp. 90-5.

Saarela, J. and Finnäs, F. (2003), "Unemployment and native language: the Finnish case", Journal of Socio-Economics, Vol. 32, pp. 59-80.

Saarela, J. and Finnäs, F. (2006), "Adjustment failures in an immigrant population: Finns in Sweden”, Social Indicators Research, Vol. 82, pp. 545-63.

Saarela, J. and Finnäs, F. (2008), "Cross-country employment propensity of Finnish migrants: evidence from linked register data”, Migration Letters, Vol. 5, pp. 63-77.

Saarela, J. and Rooth, D.-O. (2006), "How integrated are Finns in the Swedish labour market? Outcomes of free labour mobility", International Migration, Vol. 44, pp. 119-52.

Statistics Finland (2006a), "Taulukot aihealueella Muuttoliike", available at: http://pxweb2.stat. fi/database/V\%E4est\%F6/Muuttoliike/Muuttoliike.asp (accessed December 1, 2006).

Statistics Finland (2006b), "Rekisteriseloste: Väestölaskentojen pitkittäistiedosto 1970-1995", available at: www.stat.fi/meta/rekisteriselosteet/rekisteriseloste_vaestolaskenta70-95. html (accessed December 1, 2006).

Statistics Finland (2006c), "Työssäkäynti”, available at: www.stat.fi/til/tyokay/index.html (accessed December 1, 2006).

\section{Return migrant status}

505 


\section{About the authors}

Jan Saarela is adjunct professor of Population Economics and works as senior lecturer of Social Policy at Ảbo Akademi University. He earned his doctor's degree for a thesis on labour market outcomes in the bilingual area of Finland. Current research concerns the use of large-scale population register data to explore mortality differentials and migration dynamics. Focus is on how experiences from Finland can be instructive in an international setting. His work is published in various scholarly journals in economics, demography, and public health. Jan Saarela is the corresponding author and can be contacted at: jan.saarela@abo.fi

Fjalar Finnäs is professor of Demography and Statistics at Ảbo Akademi University. His thesis in 1986 concerns the demographic development of the Swedish-speaking population and the effect of bilingual marriages. He has studied various aspects within the field of demography such as general population development, family formation, divorces and fertility. In recent years the focus has been on migration and the mortality differences between Swedish-speakers and Finnish-speakers in Finland.

To purchase reprints of this article please e-mail: reprints@emeraldinsight.com Or visit our web site for further details: www.emeraldinsight.com/reprints 